\title{
INSTITUTIONAL PATH DEPENDENCE IN CLIMATE ADAPTATION: COMAN'S "SOME UNSETTLED PROBLEMS OF IRRIGATION"
}

\author{
Gary D. Libecap \\ Working Paper 16324 \\ http://www.nber.org/papers/w16324 \\ NATIONAL BUREAU OF ECONOMIC RESEARCH \\ 1050 Massachusetts Avenue \\ Cambridge, MA 02138 \\ September 2010
}

Helpful comments and suggestions were provided by Zack Donohew, Eric Edwards, P.J. Hill, Charles W. Howe, Mark Kanazawa, Clay Landry, Dean Lueck, Robert Moffitt, Trevor O'Grady, and Henry Smith. The views expressed herein are those of the author and do not necessarily reflect the views of the National Bureau of Economic Research.

NBER working papers are circulated for discussion and comment purposes. They have not been peerreviewed or been subject to the review by the NBER Board of Directors that accompanies official NBER publications.

(C) 2010 by Gary D. Libecap. All rights reserved. Short sections of text, not to exceed two paragraphs, may be quoted without explicit permission provided that full credit, including $\odot$ notice, is given to the source. 
Institutional Path Dependence in Climate Adaptation: Coman's “Some Unsettled Problems of Irrigation"

Gary D. Libecap

NBER Working Paper No. 16324

September 2010

JEL No. N51,N52,Q15,Q25,Q54

\begin{abstract}
Katharine Coman's "Some Unsettled Problems of Irrigation," published in March 1911 in the first issue of the \$P HIFDQ( FRQRP IFI5 HIIHZ addressed issues of water supply, rights, and organization. These same issues have relevance today 100 years later in face of growing concern about the availability of fresh water worldwide as demand grows and as supplies become more uncertain due to the potential effects of climate change. The central point of this article is that appropriative water rights and irrigation districts that emerged in the American West in the late 19th and early 20th centuries in response to aridity to facilitate agricultural water delivery, use, and trade raise the transaction costs today of water markets. These markets are vital for smooth re-allocation of water to higher-valued uses elsewhere in the economy and for flexible response to greater hydrological uncertainty. This institutional path dependence illustrates how past arrangements to meet conditions of the time constrain contemporary economic opportunities. They cannot be easily significantly modified or replaced ex post.
\end{abstract}

Gary D. Libecap

Bren School of Environmental Science

and Management and Economics Department

University of California, Santa Barbara

Bren Hall 4412

Santa Barbara, CA 93106-5131

and ICER

and also NBER

glibecap@bren.ucsb.edu 
Katharine Coman's “Some Unsettled Problems of Irrigation,” published in March 1911 in the first issue of the American Economic Review addressed issues of water supply, rights, and organization. These same issues have relevance today 100 years later in the face of growing concern about the availability of fresh water worldwide as demand grows and as supplies become more uncertain due to the potential effects of climate change (Barnett et al., 2008; World Water Assessment Program, 2009).

Water supply, allocation, and management are of particular consequence for the part of the United States, west of the $100^{\text {th }}$ meridian, running from North Dakota to Texas that was the focus of Coman's article. This region contains the driest parts of North America and includes a climatic transition zone where most of the continent's droughts occur (Libecap and Hansen, 2002, 92). It is also an area of rapid population growth, rising per capita incomes, and greater water demand for municipal, industrial, recreational, and environmental uses (Brewer, et al, 2008, 92).

Today, as it was in 1911, the dominant use of water is in agriculture, where as much as $80 \%$ of annual consumption occurs. Satisfying agricultural requirements as urban and environmental demands increase in the presence of possible more variable supplies requires a variety of responses, including greater conservation, desalinization, recycling, and more surface storage. But these new supply options generally are more costly than is the re-allocation of water from agriculture to areas of increased demand. Further, they are more effective when supplemented by active water markets and water prices that demonstrate opportunity costs and create incentives for efficient distribution, preservation, and wise use.

Markets, however, rely upon well-defined property rights. In 1967, Harold Demsetz hypothesized that as resource values rise, property rights would be made more precise and 
markets more complete as the benefits of doing so offset the inherent costs involved. Yet, this process of institutional change in western water is occurring more slowly and in a more complex manner than one might have predicted. In 1986, Robert A. Young asked why water markets were not more active. Twenty-four years later, one might still ask that same question. ${ }^{2}$

Generally, contemporary water markets, including permanent water rights sales and short- and long-term water leases, are local with trading confined within water basins and sectors (among adjacent irrigators, for example). Typically, exchange outside of a water basin is limited, and voluntary transactions to move water from agricultural to urban use often are very costly, and in some cases, extremely contentious. And there is virtually no private water trading across state boundaries.

Price differences illustrate the opportunity for exchange, but such comparisons are difficult to assemble because of segmented markets, limited comparable observations of trades within and across sectors, high shipping or conveyance costs, diverse regulatory regimes, and variation in quality. Accordingly, examining available price data must be done with caution, but the patterns are indicative of the thinness of many water markets and of the benefits from further re-allocation.

For instance, data assembled by Clay Landry (2010) for two regional markets, the Reno/Truckee Basin, Nevada and the South Platte Basin, Colorado, indicate significant price gaps between agriculture-to-urban and agricultural-to-agriculture transactions. For the Truckee Basin, the median price of 1,025 agriculture-to-urban water rights sales between 2002 and 2009 (2008 prices) was $\$ 17,685 /$ acre foot (an acre foot $=325,851$ gallons, about enough to meet the needs of 4 people for a year), whereas for 13 agriculture-to-agriculture water rights sales over the

\footnotetext{
${ }^{2}$ Other economists have discussed the limited nature of water markets, including Anderson and Snyder (1997), Carey and Sunding (2001), and Howitt and Hansen (2005, 59).
} 
same period the median price was $\$ 1,500 / \mathrm{AF}$. For the South Platte, the median price for 138 agriculture-to-urban sales between 2002 and 2008 was $\$ 6,519 / \mathrm{AF}$ as compared to $\$ 5,309 / \mathrm{AF}$ for 110 agriculture-to-agriculture sales. ${ }^{3}$ In another observation where quality and source are identical, groundwater directed to agriculture in Pima County, Arizona in 2006 was priced at approximately $\$ 27 / \mathrm{AF}$, whereas the same water directed to urban consumers was priced from $\$ 479$ to $\$ 3,267 / \mathrm{AF}$ through an increasing block rate structure (Brewer, et al, 2008, 92). ${ }^{4}$

Aggregating transactions across markets and time can compensate for limited comparable transactions within markets in order to gain a better sense of differences in value, recognizing the qualifiers noted above. Median prices for one-year leases across 12 western states between 1987 and 2008 are \$74/AF for agriculture-to-urban leases (204 observations) and \$19/AF for agriculture-to-agriculture leases (207 observations) and median prices are \$295/AF for agriculture-to-urban sales (1,140 observations) as compared to \$144/AF for agriculture-toagriculture sales (215 observations). ${ }^{5}$

All told, these data indicate that there are significant economic gains from transferring water from agriculture to other sectors and that price signals provide valuable incentives for investment in conservation and in farming practices that release water for use elsewhere. In light of this information, what constrains water markets today, and how are these constraints linked to

\footnotetext{
${ }^{3}$ South Platte prices are similar across sectors in part because they involve comparable purchases of mutual ditch company shares and therefore better reflect opportunity costs than is the case in the Truckee Basin where various submarkets and water sources exist. A ditch company share entitles the owner to a pro-rata percentage of the ditch company's total water supply each year.

${ }^{4}$ Some of the price difference reflects the costs of the urban water-delivery infrastructure. It is unlikely, however, that those costs account for the dramatic price difference across the two uses.

${ }^{5}$ The price data are in $2008 \$$ and are drawn from 2,765 observations of water transactions with price information between 1987 and 2009, as interpreted from discussions in the trade journal, Water Strategist and maintained at http://www.bren.ucsb.edu/news/water_transfers.htm. For sales, prices are per acre-foot of the committed flow of water. By discounting quantity flows, using the same methodology as for determining the present value of a perpetual or multi-year bond, we calculate a single committed quantity that is directly comparable to a per-acre-foot, one-year lease. Failure to do so would seriously undercount the amount of water committed for exchange in longterm contracts. See methodology described in Brewer, et al $(2008,99)$. The states included are California, Washington, Oregon, Idaho, Montana, Wyoming, Nevada, Arizona, New Mexico, Utah, Colorado, and Texas.
} 
the water supply and demand issues of concern to Katherine Coman in 1911? Addressing these questions is the focus of this article.

At the time Coman published her essay, the U.S. was in the final phase of agricultural settlement of North America, and irrigation was necessary for farming the lands west of the $100^{\text {th }}$ meridian. Because of its aridity the region had been bypassed by earlier migrants for more favorable opportunities in the Midwest and near the Pacific Coast. In 1823 a federal government survey deemed it unfit for cultivation and uninhabitable by people depending on agriculture. ${ }^{6}$ In 1879 John Wesley Powell in his Report on the Arid Lands of North America delivered to Congress described the climatic challenges of the West and the need to modify settlement policies in order to promote successful economies. The region's relative dryness is shown by the white space indicating low precipitation in Figure 1 as presented by Powell.

Figure 1

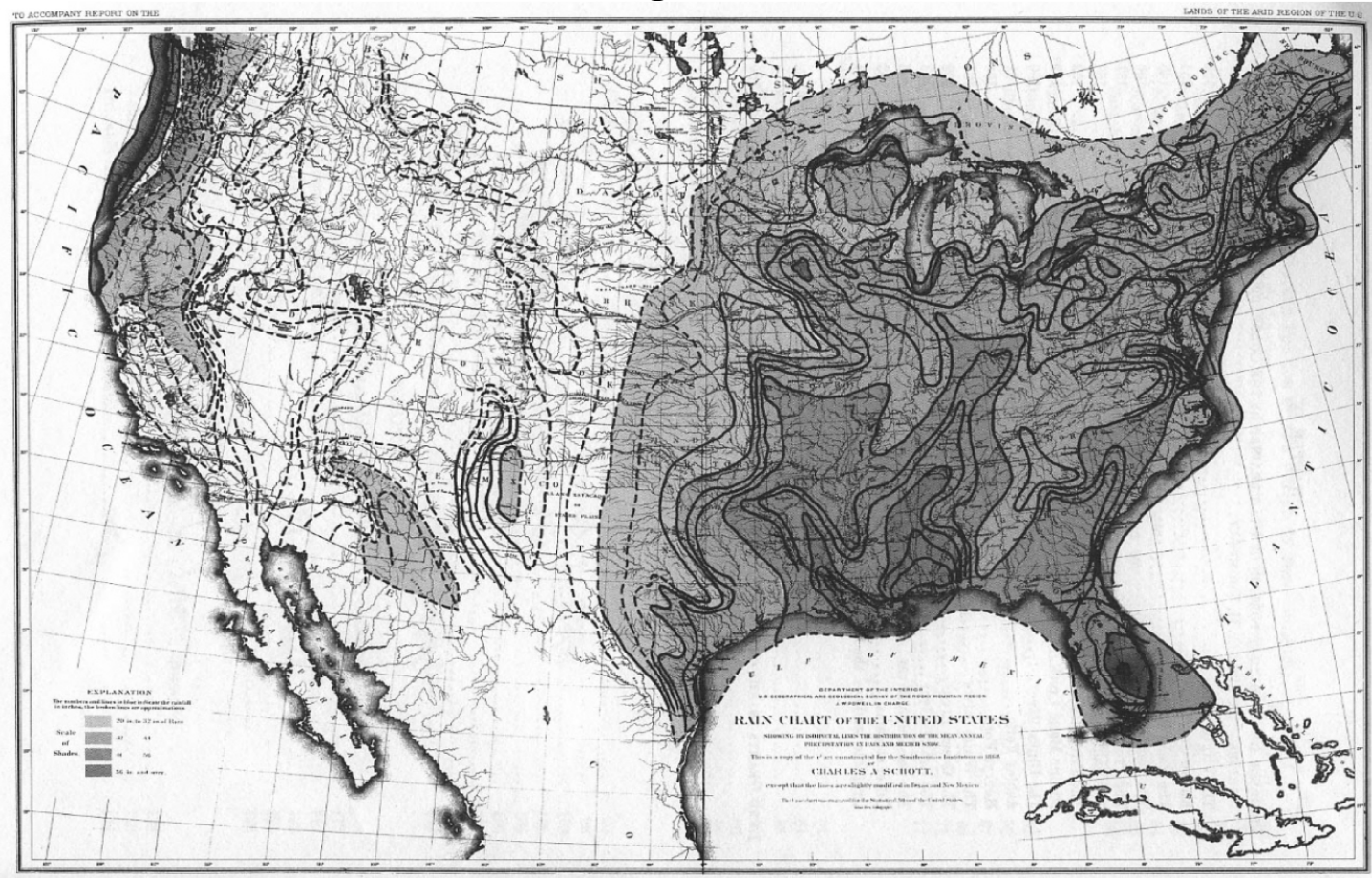

Source: Powell, 1879, frontispiece, reprinted in Worster $(2001,349)$.

\footnotetext{
6 The region was labelled “The Great American Desert,"(Meinig, 1993, 76) http://en.wikipedia.org/wiki/Great_American_Desert
} 
The key point made here is that the institutions that emerged to facilitate agriculture in response to the region's aridity raise the costs today of re-allocating water to higher-valued uses and of flexibly responding to hydrological uncertainty due to climate change. Given historical circumstances, water rights and supply organizations may not have developed differently. Even so, it is worthwhile understanding how they evolved and the roles they play in today's water markets. Further, these institutional restrictions on markets illustrate how past arrangements to meet conditions of the time constrain contemporary economic opportunities. They cannot be easily significantly modified or replaced ex post. ${ }^{7}$

\section{The Climate Information Problem.}

The climate information problem encountered in the early 20th century West is similar to that faced more broadly today. At the time, there was little experience with aridity; limited data were available about the climate of the region; and competing models existed for analyzing and developing appropriate individual and government responses. These conditions are analogous to debates over contemporary climate-change projections; how to interpret them; determining the role of human activity; and deciding what they might mean for policy (Nordhaus, 2008; Pindyck, 2010; Weitzman 2010).

As in Coman's time, how climate differences will affect water supply today remains unclear. Water supply variability has been modelled on historical precipitation patterns, but they will not continue to hold under projected climate change scenarios. Present climate projections indicate changes in precipitation, both in type and timing, leading to reduced confidence about water supply reliability, affecting agricultural, municipal, industrial, recreational, and

\footnotetext{
${ }^{7}$ The long-term roles of institutions in economic decision making, performance, and resource use are discussed in North (1990) and Ostrom (1990).
} 
environmental uses. ${ }^{8}$ For example, progressively earlier snowmelt is predicted. This is a vital source of water in the western U.S., supplying between $50 \%$ and $80 \%$ of annual stream flow volume. Early snowmelt will change stream flow, modifying time-honored assumptions about the predictability and seasonal deliveries of water and decreasing summer stream volumes with important implications for warm-season water supplies (Stewart, Cayan, and Dettinger, 2005).

New water demands are emerging just as supply uncertainty is increasing. Past water allocation in the West occurred prior to reliable technical information on the amount of water available, and supply organizations were directed to agriculture (Coman, 1911, 8). ${ }^{9}$ Well-defined water rights and flexible markets can provide information on current consumption patterns and alternative values, incentives for adjustments in use, smoother distribution to meet competing claims, and more effective responses to climate change-induced supply shocks. In this way, water markets can facilitate more rapid and flexible adaptation to new demands and to climate change, processes that are especially important for arid and semi-arid regions like the U.S. West. $^{10}$

In the late 19 th and early 20 th centuries as migrants were moving into the area, U.S. land laws governed the distribution of federal lands. The primary vehicle was the 1862 Homestead Act that authorized small farms of up to160 acres. These allotments had worked well in the Midwest and the question was, would they work as effectively in the drier West? Subsequently, these farms would be shown to be far too small for arid or semi-arid regions with many homesteads failing (Libecap and Hansen, 2002; Hansen and Libecap, 2004a).

\footnotetext{
${ }^{8}$ See Barnett, et al, (2005) for discussion of the impact of climate change on snow packs and water availability.

${ }^{9}$ Consider the 1922 allocation of Colorado River water among the states based on river flows that subsequently were found to be far above long-term averages ( http://en.wikipedia.org/wiki/Colorado_River_Compact).

${ }^{10}$ Current research indicates an increase in precipitation overall, but also less precipitation in arid regions, such as observed precipitation decreases in Southern Africa and Australia (Ragab and Prudhomme, 2002).
} 
Indeed, John Wesley Powell, who explored the region and understood the climate's implications for farming, called for much larger land allocations. He suggested either pasture homesteads of 2,560 acres for raising livestock within grazing districts of nine or more ranchers or cooperative irrigation districts for farming with group members receiving individual plots of 80 acres and shares of available water. The cooperative irrigation district proposal was built around Powell's experience with Mormon settlements in southern Utah as noted by Coman $(1911,6) .{ }^{11}$ These recommendations were not implemented by skeptical members of Congress who were unconvinced about asserted climatic constraints and who wanted to maintain politically-attractive piecemeal land-distribution policies that offered some land for many constituents. Accordingly, only minimal modifications were made in the land laws. ${ }^{12}$

Three hypotheses emerged in reaction to the climate problem and the primitive science that existed regarding it. One, "Rain-Follows-the-Plow," was prominent until the last decade of the $19^{\text {th }}$ century. It held that the climate could be changed by human activity, such as the planting of crops and the filling of reservoirs, so that changes in farm size, crops, and farming practices were not necessary. As with other optimistic predictions of the Progressive Era, the view was that people could beneficially mold the climate in their behalf, an ironic conclusion given current concerns about possible negative climatic effects of human-generated greenhouse gas emissions. Because of the region's highly variable precipitation, the hypothesis seemed to be confirmed

\footnotetext{
${ }^{11}$ Powell's 1879 report had two bills, one for creating irrigation districts and the other for grazing homesteads. See Worster (2001, 356-7).

${ }^{12}$ The disposal of federal lands was a key plumb for politicians and Powell's suggested distributions would have sharply reduced the number of potential homestead opportunities at a time of tightening land supplies. Indeed, the U.S. Census declared the frontier closed in 1890. See Hansen and Libecap (2004a) and Libecap (2007) for discussion of the long-term implications of land policy for farm failure and the ownership of western range and forest lands.
} 
during a period of high rainfall, only to be finally rejected when a devastating drought returned in Kansas in 1893-4 (Libecap and Hansen, 2002). ${ }^{13}$

Another hypothesis was that precipitation could be stored deep in the subsoil through proper cultivation during wet periods and drawn upon during drought. This was the central tenant of dryfarming doctrine that was well-known between 1905 and 1920. The doctrine held that water could be captured after a rain through intense tillage, mulching, and soil packing by farmers. According to the doctrine, stored moisture would percolate upward through the soil via capillary action as needed to nourish plant roots. The hypothesis, unfortunately for those who bet the farm on it, did not pass empirical test. Another intense drought from 1917-21 in the northern Great Plains brought widespread homestead collapse and the end of dryfarming doctrine. ${ }^{14}$

The third hypothesis was that small-farm agriculture could thrive in a semi-arid region with irrigation. This was a far more successful notion, and the subject of Coman's article. Between 1890 and 1978, covering the time of most agricultural settlement of the West and subsequent expansion of the agricultural economy, irrigated acreage in 17 western states grew from 3.6 million acres to 43.4 million acres. ${ }^{15}$ This irrigation expansion required investment in infrastructure for capturing, storing, and delivering water, facilitated by institutional adaptation through new water rights and new water supply organizations.

\section{Western Water Rights and Their Long-Term Impact on Water Markets.}

\footnotetext{
${ }^{13}$ To get a sense of the region's low level and variability of precipitation consider the following data for 4 Midwestern and 4 Western states from 1895-1945:

Precipitation (Inches)

Ohio, Indiana, Illinois and Iowa $\quad 36.30$

CV

0.13

$\mathrm{SD}$

Arizona, Colorado, Utah, Montana

13.96

0.19

4.70

Source: http://lwf.ncdc.noaa.gov/oa/climate/research/cag3/state.html

${ }^{14}$ Hansen and Libecap (2004b) examine the legacy of excessive cultivation on small homesteads for the 1930's Dust Bowl.

${ }^{15}$ See Bretsen and Hill $(2006,239)$ for irrigation data. Starting in 1890 the U.S. Census presents irrigation data, in some cases in a special volume, "Irrigation and Drainage." See Pisani (1984) for historical analysis.
} 
In eastern states water rights are based on ownership of land appurtenant to streams, and land owners are granted correlative rights to reasonable use of water so long as doing so does not harm other riparians. Most applications, such as transportation and power generation, are nonconsumptive and do not diminish downstream flows. Riparian rights are not forfeited due to lack of use, and are transferable only with adjacent land (Getches 1997, 33; Rose, 1990; Smith, 2008).

Except for certain areas, riparian water rights are not effective for the more arid West, where water supplies are both lower and unevenly distributed relative to the East. Instead, water diversion through ditches, canals, and aqueducts is necessary for economic activities in areas remote from water sources (Coman, 1911, 3, 5; Kanazawa, 1998, 2010; Pisani, 1996, 14, 2437). ${ }^{16}$ Following the same property rights allocation practices used for western agricultural land and hard rock minerals, prior-appropriation rights to water are assigned through first possession, or first-in-time, first-in-right (Lueck, 1995; Libecap, 2007).

Appropriative water rights grant usufructory or possessory rights to a fixed quantity or flow of water, usually measured in cubic feet per second, cfs, for diversion from a stream, based on the date of the original claim (Johnson, et al, 1981, 282; Smith, 2008, 452, 467-72). Those with the earliest claims or senior rights have the highest priority and subsequent claimants have lower-priority or junior rights. Diversions are accommodated by rank so long as there is sufficient stream flow. Accordingly during drought, water is progressively rationed by priority of right, and junior diversions may be halted.

\footnotetext{
${ }^{16}$ Appropriative water rights developed to support hydraulic mining of dry hillside ore deposits and then were applied to farming areas to support irrigation. Kanazawa $(2010,18-20)$ examines the development of water rights in western mining districts and finds that every district that was exclusively "dry" adopted prior appropriation and every district that was exclusively "wet" did not.
} 
Appropriative rights are not tied to the land. Therefore they can be sold or leased for use elsewhere, creating a basis for water markets and security for investment in water-delivery infrastructure, agriculture, and other endeavors. ${ }^{17}$

Appropriative rights are conditional upon water being placed into beneficial use- - the "use-it-or-lose-it" mandate--and no injury to third parties. ${ }^{18}$ Beneficial use is a low-cost way of determining if there is excess water to be appropriated. The driest western states--Arizona, Colorado, Idaho, Montana, New Mexico, Utah, and Wyoming recognize only appropriative water rights whereas, the wetter states of California, the Dakotas, Kansas, Nebraska, Oklahoma, Oregon, Texas, and Washington recognize both riparian and appropriative institutions (Kanazawa, 1998). Beneficial use, however, contributes to waste as rights holders devote water intensively to low marginal-value "approved" applications in order to maintain ownership and neglect higher marginal-value uses that may not be considered consistent with the doctrine, which is a political decision. ${ }^{19}$

Under prior appropriation there is a critical interdependence among diverters from the same water source with different priority rights. As much as $50 \%$ of senior diversion is not consumed by plants or evaporation and flows back to the stream or percolates down to the aquifer to be available for subsequent users (Young, 1986, 1144). During times of drought when natural stream volumes are diminished and senior appropriators have first access to them, junior appropriators are especially dependent upon these return flows. They bear most of the downside

\footnotetext{
${ }^{17}$ Tenure security provided by appropriative water rights is emphasized by Burness and Quirk $(1979,34)$.

${ }^{18}$ A water right not used for an accepted beneficial purpose for a predetermined period may lapse under the doctrine of abandonment.

${ }^{19}$ States list preferred uses that are consistent with beneficial use and the public interest, such as domestic, municipal, irrigation and so forth and these preferred uses can be adjusted with changes in water values and constituent-group politics. Coman $(1911,8)$ discusses incentives to over use water in order to hold the right. The problem of providing in-stream flows for recreation and environmental benefits while being consistent with beneficial use is discussed by Anderson and Johnson (1986) and Scarborough (2010)
} 
risk of drought. ${ }^{20}$ Actions by senior rights holders to change the location, nature, or timing of use can affect water consumption and thereby influence the amount of water released downstream. Accordingly, water trading from agriculture to urban uses that involves export out of the basin and thereby reducing return flows can impair third parties and is subject to state regulation to insure that no damage is inflicted on junior diverters (Getches, 1997, 161).

Applications for transferring rights are filed with the relevant state regulatory agency for approval. The applicant specifies the location and amount of water, the duration of the contract, the timing of the exchange, type of water right involved, consumptive use, and possibly hydraulic and other legal information. Objections can be filed, and the burden of proof of nonimpairment rests with the applicant. The regulatory process and the costs associated with it vary across states, in part because the "no harm" mandate is defined differently (Colby, et. al, 1989; Colby, 1990; MacDonnell, 1990, Vol. I, 38-57; Thompson, 1993, 704-5).

By assigning ownership to specified amounts or flows of a highly variable resource stock, appropriative water rights exacerbate third-party effects occasioned by trades initiated by senior rights holders. ${ }^{21}$ The potential for third-party impairment raises the likelihood of protests and litigation by junior rights holders over water transactions. ${ }^{22}$ If instead, water rights were granted as portions or shares of the annual total allowable withdrawal from a water basin, adjustable according to precipitation, then all appropriators would share in any adjustments in total diversions due to precipitation shortfalls. Under this setting "junior" parties would not be differentially impacted by drought or as dependent upon released flows. Hence, the potential for

\footnotetext{
${ }^{20}$ Burness and Quirk $(1979,1980)$ emphasize the unequal sharing of risk among water appropriators as a key source of inefficiency for appropriative water rights.

${ }^{21}$ Similarly, Pisani's $(1992,33)$ analysis of the development of western water law is critical of prior appropriation.

${ }^{22}$ The comparative inflexibility of fixed quantity allotments in the face of variable stocks has resulted in policy changes in other settings. New Zealand's individual transferable quota system in fisheries, first implemented in 1986 involved catch tonnage allotments. These proved to be too large in the aggregate when fish stocks plummeted so that in 1990, they were replaced with catch shares (Connor and Shallard, 2010, 348-9).
} 
third-party harm from trades would be reduced, especially if they are limited to consumptive use (Burness and Quirk, 1980, 124; Johnson, et al, 1981, 274).

Until the latter part of the $20^{\text {th }}$ century, third-party impairment generally was not an issue because most traded water stayed within the local agricultural community where demand was concentrated. In the face of contemporary pressures to re-allocate water to other uses, however, protests of harm can be significant barriers to trade. The no-harm standard can be so vague and the range of standing so broad for parties to challenge proposed exchanges that they can become mired in costly disputes and delay. This situation tends to keep water locked in agriculture even though there are higher marginal values elsewhere. ${ }^{23}$

The need to effectively address the interconnectivity of water diversions in the West was observed early. As noted above, one of John Wesley Powell's 1879 legislative drafts called for cooperative water rights and irrigation districts (Worster, 2001, 351). His recommendations, however, were not followed. At a time when agricultural use was viewed as the highest value for water, third-party effects did not loom large as they do today. There is contemporary precedent, however, for institutions that reduce them by assigning water shares rather than fixed quantities. The Colorado Big-Thompson (CBT) Project is an important and generally unique example.

The CBT is a trans-basin diversion, bringing supplemental water from the Colorado River Basin to the South Platte River Basin in north eastern Colorado, supplying about $30 \%$ of the water in that region (Howe and Goemans, 2003, 1056). The project was constructed by the Bureau of Reclamation (BOR) between 1938 and 1957 and is managed by the Northern Colorado Conservancy District (Tyler, 1992). The CBT annually delivers an average of 270,000 AF for agricultural, municipal, and industrial uses (http://www.ncwcd.org/; Howe and Goemans,

\footnotetext{
${ }^{23}$ Hanak (2003) analyzes technological and pecuniary third-party effects and their impact on support for water markets. The regulatory process and its costs are discussed by Colby $(1988 ; 1990)$ and by MacDonnell $(1990$, Vol. I, 38-70). As Burness and Quirk (1980) note, there are other institutional and political barriers to water trade.
} 
2003). The water is allocated through tradable uniform water units, whereby each is a share of the annual amount of water available to the District. ${ }^{24}$ The water in each unit fluctuates annually based on water supply, and all shares are adjusted in the same manner. Because shares are homogenous, transfers across users, especially across sectors, occur with minimal fees and paperwork (Thompson, 1993, 719; Carey and Sunding, 2001, 305; Howe and Goemans, 2003, 1058-9). Additionally, the District administers proposed trades rather than the larger and more politically and institutionally complex BOR. For these reasons, the Colorado Big Thompson is by far the most active water market in the West in terms of numbers of trades, and sales prices for all uses are comparable as they should be when opportunity costs are incorporated, water quality and right priority are the same, and transaction costs are low. ${ }^{25}$

The CBT is unusual among Bureau of Reclamation projects in that it supplies new water stored in reservoirs to existing users. As imported water from another basin, all return flows are owned by the Northern Colorado Conservancy District and cannot be claimed separately by other parties. This provision reduces conflicts over potential third-party impairment in water trades. ${ }^{26}$ Further, the initial distribution was in support of on-going irrigation from a single source. There was threshold objective of providing enough additional water so that each farm would have $2.5 \mathrm{AF} /$ acre. Because the required supplements varied across farms, there was no demand for fixed allotments, and it took some time for all of the shares to be subscribed (Knight,

\footnotetext{
${ }^{24}$ As discussed by Howe, Schurmeier, and Shaw $(1986,443)$, each share or unit is $1 / 310,000$ of the water available to the Northern Colorado Conservancy District.

${ }^{25}$ For example, sample agriculture-to-urban and agriculture-to-agriculture sales were priced at $\$ 9,350$ and $\$ 9,300 /$ unit respectively, as reported in the October 2008 Water Strategist, p. 7. The CBT also has the advantage of using reservoir water, imported from elsewhere, providing a less complex case than when flowing streams are the water sources (Howitt and Hansen, 2005, 60).

${ }^{26}$ The notion is that the natural flow claimed by existing water rights holders is not negatively affected by the import or trade of new water. According to Clay Landry the argument could be made that stored water within a basin has similar benefits as imported water and should not be held to traditional third-party injury tests. In fact, the BOR treats its other Colorado River storage contracts currently with this view by allowing the full quantity of the contract to be transferred and not limiting it to historical consumptive use to address potential injury issues.
} 
1956; Howe, Schurmeier, and Shaw, 1986, 443). The units, however, could be traded among all users, agricultural, urban, and industrial alike, within the District. ${ }^{27}$ The issue of whether such proportional shares might be adopted more broadly in the West in place of existing prior appropriation rights is examined in the conclusion.

\section{Irrigation Districts and Their Long-Term Impact on Water Markets.}

Water supply networks require initial fixed investments in dams, reservoirs, canals, and feeder ditches to capture, store, and deliver water. Irrigated farms also require upfront investments in local ditches and water-intensive annual and perennial crops. This setting creates contracting hazards for investors in water supply organizations and for farmers. Both parties are dependent upon one another, but non-deployable capital, bilateral monopoly, holdup, free-riding, and timing problems can undermine either endeavor.

These issues are examined by Stephen N. Bretsen and Peter J. Hill (2006, 288-92). The fixed costs of an irrigation network mean that there is likely to be only one water supply organization in any location, and it relies upon farmer demand in its delivery area. There is potential for either party to engage in opportunism to extract the associated quasi rents (Klein et al, 1978). The supply organization as monopolist can threaten to deny water during key growing periods to gain higher rates, and farmers can organize for lower prices by withholding demand. ${ }^{28}$ Long-term price and delivery contracts between water supply organizations and farmers also are complicated by the unpredictability of precipitation and stream flow. Right-of-way holdup is possible because canals and ditches cross multiple land parcels in building an irrigation network of sufficient size. Free-riding is a threat as farmers located at the head of a ditch are less

\footnotetext{
${ }^{27}$ The CBT region has a mix of agricultural and rapidly growing urban users, with urban purchases increasing as a share of total market activity, often with leases back to agriculture.

${ }^{28}$ Bilateral monopoly bargaining in a similar context between the Los Angeles Department of Water and Power and Owens Valley, California farmers is examined by Libecap (2008a).
} 
motivated to provide maintenance to insure water flow to up-ditch farmers. Finally, in terms of timing and sequence of investment, agriculture is not feasible without upfront irrigation capital, but such investment requires agricultural demand to generate favorable rates of return for attracting funds. Hence, coordination of investment is a challenge for both parties. Vertical integration (Williamson, 1971) generally is not a solution to these bargaining problems because optimal farm sizes (Allen and Lueck, 1998) are far less than economies-of-scale in irrigation infrastructure mandate.

The transaction costs associated with optimal investment underlay the "unsettled problems of irrigation" discussed by Coman (1911, 9-10), and they resulted in different institutional responses with long-term consequences for contemporary water markets.

In relatively straightforward cases, unincorporated, non-profit mutual irrigation associations are formed by small groups of farmers, who jointly agree to construct and maintain a water delivery infrastructure. Depending on the case, farmers may retain their individual water rights and priorities with their water shares based on them or all members may have the same priority with shares allocated based on participation in the ditch association. In some states unincorporated mutuals are granted the authority to condemn property for right-of-way. Because of their low cost for simple networks, unincorporated mutual irrigation associations are popular, covering 46\% of irrigated acreage in the West in 1910 and 56\% in 1978 (Bretsen and Hill 2006, 293-4).

Larger projects, however, require more complex arrangements, such as incorporated mutual irrigation companies or commercial irrigation companies, as discussed by Coman (1911, 10-15). Mutuals are non-profits organized by farmers as shareholders with either the company holding the water rights and supplying water according to shares held by farmers or the farmers 
retaining their rights and receiving the water as specified (Hutchins, 1929). Because they are initiated and managed by relatively homogeneous groups of farmers, mutuals reduce the coordination cost of water delivery. They supplied 30\% of irrigated acreage in 1910, declining to 16\% by 1978 (Bretsen and Hill, 2006, 293-4) due to the growth of irrigation districts as discussed below.

For-profit, commercial irrigation companies are among the earliest irrigation institutions. They include development companies that assemble land parcels, provide irrigation, and then profit from the sale of irrigated land; commercial water companies that sell water to farmers; and public utilities that sell water to any party in their service area (Hutchins, 1930). In the early 20th century they built ahead of agricultural settlement and failed when they misjudged demand and could not cover outstanding construction bonds. Commercial irrigation companies declined from providing $11 \%$ of irrigated acreage in 1910 to $0.5 \%$ by 1978 (Bretsen and Hill, 2006, 293-4).

The most important water supply organization to emerge and the one posing the greatest implications for contemporary water markets is the irrigation district (Hutchins, 1931; Leshy, 1982). They covered $4 \%$ of irrigated acreage in 1910 and nearly $25 \%$ by 1978 (Bretsen and Hill, 2006, 293, 312-27). ${ }^{29}$ Many districts have rights to very large amounts of water. One of the country's largest irrigation districts, the Imperial Irrigation District of Southern California, annually diverts 2.8 million AF of Colorado River water, nearly two-thirds of California's legal share of the river. ${ }^{30}$ The district includes 495,000 acres of cropland as well as urban areas.

Irrigation districts vary across the western states. In general they are political subdivisions and have eminent domain powers to address hold-up in laying the network; ability

\footnotetext{
${ }^{29}$ Irrigation districts were first authorized by the Wright Act of 1887 in California and are discussed by Kanazawa (1998, 181) and Pisani (1984, 129-53, 250, 283).

${ }^{30}$ Under the 1922 Colorado River Compact (http://www.usbr.gov/lc/region/g1000/lawofrvr.html) and the U.S. Supreme Court decision in Arizona v. California 373 U.S. 546, California is granted 4.4 million AF annually. It regularly diverts 5.1 to 5.3 million AF, however (Haddad, 2000, 70-1; Glennon, 2009, 258).
} 
to tax all lands within the district to cover expenses; power to coerce membership in the district once the required majority of voters agree; and authority to issue tax-exempt bonds for construction, backed by assessments against the land within the district. Moreover, they have direct access to Federal Bureau of Reclamation water, following Congressional legislation in 1922 and 1926 authorizing, and then requiring, the agency to contract only with irrigation districts in the provision of federal agricultural water. ${ }^{31}$

Initially, Bureau of Reclamation water was to go directly to farmers, but because irrigation was a precondition for agriculture there were few incumbent farms to receive it. Accordingly, the agency focused on supplying existing irrigation districts, usually with a subsidy (Wahl, 1989). This shift, however, changed irrigation districts from being locally-controlled institutions that could be responsive to changing water demands to being an integral facet of the federal agricultural water supply system. This framework with its many constituencies and restrictive provisions for use raises the costs of moving water to non-agricultural uses.

Districts are launched by petitions to county commissioners from land owners seeking to construct an irrigation network. Their irrigation plan is reviewed and subject to vote. The nature of the franchise and required approval majorities varies among the states with important longterm ramifications for water rights and governance of irrigation districts.

In many states, only land owners within the proposed district vote and comprise the governing board. ${ }^{32}$ In California, Idaho, and Kansas, however, as a trade-off for receiving governmental powers, all registered voters may be eligible. A wide franchise grants decision making over water rights, allocation, and management to a diverse group of non-farm

\footnotetext{
${ }^{31}$ Bretsen and Hill $(2006,317 ;$ 2009, 739). The Federal Bureau of Reclamation was created in 1902 and is the largest wholesaler of water in the U.S. providing irrigation water for 140,000 farms covering 10,000,000 acres in 17 western states http://www.usbr.gov/main/about/.

${ }^{32}$ As an indication of the differences that exist across states, however, in Colorado governing boards are appointed by water courts with neither the taxed public or land owners having a direct vote.
} 
community members, tenant farmers, and land owners, and their interests are unlikely to coincide (Thompson, 1993, 678, 728, 740; Rosen and Sexton, 1993, 40-1, 49-52; Bretsen and Hill, 2006, 320-23; 2009, 737).

Accordingly, in these public irrigation districts water is common or community-wide property where it is uncertain who has authority to change use or trade water. ${ }^{33}$ Because the disbursement of benefits and costs is unclear, farmers lack incentives to idle marginal land, invest in on-farm water conservation, or to participate in pareto-improving, long-term water trades.

Concern about possible third-party effects resulting from reduced demand for agricultural labor or farm machinery following a switch to less water-intensive crops or fallowing land are important factors in community opposition to water trades. Historically when water was less scarce and agriculture the dominant use, a diffuse water rights relationship between the district and its members was of little consequence. Transfers were among members and arranged informally to meet seasonal shortfalls. Today, as marginal water values outside of agriculture have become much higher than those within it, long-term transfers increasingly are to out-ofdistrict users. Potential revenues to water sellers especially are large for districts near urban areas or with conveyance to them. For example, Robert Glennon reports $(2002,207)$ that land developers near the Grand Canyon National Park offered \$20,000/AF in 2001 for Colorado River water used by farmers in the Imperial Irrigation District (IID) who paid $\$ 13.50 / \mathrm{AF}^{34}$

In light of the high prices offered for urban water there is potential for opportunism as additional claimants attempt to secure a portion of the rents. Resolving the many disputes that can arise in the presence of large numbers of varied parties can be so difficult as to delay, reduce,

\footnotetext{
${ }^{33}$ Most districts formally hold the water rights and deliver water to their members. In other cases, members retain the water rights and have service contracts with the district (Thompson, 1993, 687).

${ }^{34}$ Colorado River water not used by the IID could have been intercepted for upstream use.
} 
or block water trades. ${ }^{35}$ The importance of these issues varies across the states according to the property rights and governance organizations that exist within irrigation districts.

The implications of irrigation district structures for water trading are illustrated by the comparative experiences of two California districts, the public Imperial Irrigation District and the nearby private Palo Verde Irrigation District (PVID), where only landowners determine board membership and policies (Rosen and Sexton, 1993, 43-51; Haddad, 2000, 74-92; Glennon, 2009, 258-71; Bretsen and Hill, 2009, 756-60).

Negotiations between the IID governing board and officials of the Metropolitan Water District of Southern California (MWD) and the San Diego County Water Authority (SDCWA) for long-term water leases occurred between 1984 and 2003. Agreements were reached, but collapsed in the face of opposition from a variety of parties. Only after the intervention of the U.S. Department of the Interior that administers Colorado River water and that supported a reallocation of IID water was an agreement finally concluded in 2003 to transfer over 30 million AF to urban users over 75 years. ${ }^{36}$ Because fallowing was so contentious, water for transfer had to be secured through ditch lining to reduce seepage even though Rosen and Sexton $(1993,51)$ argue that fallowing was more cost effective.

Negotiations between the PVID governing board and the MWD were much smoother, faster, and less contentious. The PVID also is a large district, irrigating 131,298 acres with $450,000 \mathrm{AF}$ of water diverted annually from the Colorado River. ${ }^{37}$ One set of negotiations over water began in 1986 and were successfully concluded in 1992. Another started in 2002 with

\footnotetext{
${ }^{35}$ This is not to say that distributional issues are irrelevant, but rather to point out the costs of resolving them and how this impacts water markets. Given the allocative benefits often associated with a redistribution of water, the revenues to address equity concerns exist, but the bargaining involving many competing parties may be intractable. Hanak's $(2003,81)$ study indicates that the negative effects of fallowing may be small.

${ }^{36}$ According to Glennon $(2009,258-64 ; 270-71)$ money was included in the agreement for community compensation. As it turns out, feared negative third-party effects generally did not materialize, but had a critical impact on the negotiations.

${ }^{37}$ www.pvid.org/; http://westernfarmpress.com/news/farming_water_transfer_thats/
} 
agreement in 2004. Both involved dry-year options, whereby farmers were to fallow designated land when requested by the MWD and to release the water to the agency for urban delivery (Haddad, 2000, 95-115). The MWD set up a fund to address third-party effects in the community. These, however, did not play a significant role in the negotiations (Glennon, 2009, 264-71; Northwest Economic Associates, 2004, 9, 31-8).

\section{Conclusion.}

In 1911, Katharine Coman wrote about the problems of agricultural development under new climatic conditions. Key institutional innovations in response to aridity were appropriative water rights that allow for fixed amounts of water to be diverted from stream flows for remote irrigation and irrigation districts that construct, deliver, and maintain water networks. Both represented practical responses for conditions faced when water use was dominantly within agriculture.

These two institutions are much less effective today for market transactions of water out of agriculture in light of new demands and greater supply uncertainty associated with climate change. Indeed, by exacerbating return-flow externalities and by diluting property rights and decision-making over water use and distribution, they raise the costs of exchange. Their arrangements are important reasons why contemporary water markets remain local and largely directed toward trade among irrigators, despite apparent high marginal values outside of agriculture.

Water is both a private and public resource with multiple interdependent uses and fluid characteristics. These factors raise bounding and measurement costs so that defining property rights to water would be more problematical in any case than for stationary resources, like land 
(Hanemann, 2006; Smith, 2008). ${ }^{38}$ Appropriative rights structures and public irrigation districts, however, add to the costs of property rights definition and trade.

Even so, they are likely to be importantly modified or replaced only at considerable cost. Developed to meet past economic conditions, they cannot be adjusted easily in response to new circumstances. There are, however, no obvious dynamic efficiency implications from their structures. These institutions were implemented based on prices and information available at the time. Subsequent changes in water supply and demand have emerged in a manner that would have been impossible to predict. Defining water rights in terms of shares rather than in fixed, diverted quantities would have required knowledge of total flows, information only more recently available for many basins. Further, assigning shares would have posed significant collective decision-making and monitoring costs, especially in basins with many heterogeneous users. $^{39}$

Constituencies exist with direct stakes in these arrangements, including senior rights holders and irrigation district board members, as well as those with indirect stakes, including diverse members of agricultural communities. The parties have expectations about the flow of benefits and costs of water and any institutional change would require their support. Given the uncertainties regarding the nature of rents from a new rights arrangement or water supply organization, such support may not be forthcoming, even in the face of compensation generated

\footnotetext{
${ }^{38}$ As argued by Smith $(2008,458-66,475-78)$ fluid resources like water, spectrum, and information are difficult to exclude entry and hence are likely to be semi-commons with aspects of private and common ownership for accommodating interlocking uses. A common property or regulatory institutional response (governance), however, raises the costs of subsequently defining property rights for transfers to new users and new uses that require exclusion.

${ }^{39}$ Early in the allocation process, diversion was much less costly to define and agree to than shares. Johnson and Libecap (1982), Wiggins and Libecap (1985), Libecap and Smith (1999), and Libecap (2008b) describe the difficulties of reaching agreement on shares or quotas in existing fisheries and oil and gas reservoirs until the resource is near collapse or exhaustion.
} 
from the gains of improved water allocation and administration. As opportunity costs increase, however, institutional adjustment is likely. ${ }^{40}$

Accordingly, water markets are apt to remain more limited than conveyance costs and quality differences alone would suggest. There are real institutional path dependencies that mold transaction costs, the extent of markets, and the nature of resource use, management, and investment. $^{41}$

\section{References}

Allen, Douglas W., and Dean Lueck, (1998), "The Nature of the Farm," Journal of Law and Economics 41 (2, pt. 1): 343-86.

Anderson, Terry and Ronald N. Johnson (1986), "The Problem of Instream Flows," Economic Inquiry 24 (4): 535-53.

Anderson, Terry and Pamela Snyder, (1997), Water Markets: Priming the Invisible Pump Washington D.C.: Cato Institute.

Barnett, Tim P., David W. Pierce, Hugo G. Halliday, Celine Bonfils, Benjamin D. Santer, Tapash Das, Govindasamy Bala, Andrew W. Wood, Toru Nozawa, Arthur A. Mirin, Daniel R. Caya, and Michael D. Dettinger, (2008), "Human-induced Changes in the Hydrology of the Western United States." Science 319: 1080-1083.

Barnett, T. P. Barnett, J. C. Adam, and D. P. Lettenmaier, (2005), "Potential Impacts of a Warming Climate on Water Availability in Snow-dominated Regions, Nature, 438: 303309.

Bretsen, Stephen N. and Peter J. Hill, (2006), "Irrigation Institutions in the American West," UCLA Journal of Environmental Law and Policy 25(2): 283-31

\footnotetext{
${ }^{40}$ For example, Richards (2008) finds voluntary modification of appropriative water rights in five severely overallocated and important water basins in New Mexico to protect high marginal value junior rights holders and to stop excessive withdrawals in the face of growing demand and highly-variable supplies. And as noted above, in-stream flows for recreational and environmental purposes also have been recognized by western states as beneficial uses.

${ }^{41}$ These path dependencies emphasize the importance of careful institutional design when property rights are being created. While path dependence in current institutions may be efficient ex post, the lesson is that future uncertainties and transaction costs should factor more heavily in the rights creation stage then perhaps they have in the past. I thank Trevor O'Grady for emphasizing this point.
} 
Bretsen, Stephen N. and Peter J. Hill, (2009), "Water Markets as a Tragedy of the Anticommons," William and Mary Environmental Law and Policy Review 33 (3): 723 83.

Brewer, Jedidiah R, Robert Glennon, Alan Ker, and Gary D. Libecap, (2008), "Water Markets in the West: Prices, Trading, and Contractual Flows.” Economic Inquiry, 46(2): 91-112.

Brookshire, David S., Bonnie Colby, Mary Ewers, and Philip T. Ganderton, (2004), "Market Prices for Water in the Semiarid West of the United States," Water Resources Research 40 W09S04.

Burness, H. Stuart and James P. Quirk, (1979), “Appropriative Water Rights and The Efficient Allocation of Resources," American Economic Review, 69(1): 25-37.

Burness, H. Stuart and James P. Quirk, (1980), "Water Law, Water Transfers, and Economic Efficiency: The Colorado River," Journal of Law and Economics 23(1): 111-34.

Carey, Janis M. and David L. Sunding, (2001), "Emerging markets in Water: a Comparative Analysis of the Central Valley and Colorado Big Thompson Projects", Natural Resources Journal 41 (Spring): 283-328.

Colby, Bonnie G. (1988), "Economic Impacts of Water Law-State Law and Water Market Development in the Southwest," Natural Resources Journal 28:721-49.

Colby, Bonnie G. (1990), "Transaction Costs and Efficiency in Western Water Allocation," American Journal of Agricultural Economics, December: 1184-92.

Colby, Bonnie G., Mark A. McGinnis, Ken Rait, (1989), "Procedural Aspects of State Water Law: Transferring Water Rights in the Western States, 31 (4), Arizona Law Review, 697720.

Connor, Robin and Bruce Shallard (2010), "Evolving Governance in New Zealand Fisheries," in R. Quentin Grafton, Ray Hilborn, Dale Squires, Maree Tait, and Meryl J. Williams, eds., Handbook of Marine Fisheries Conservation and Management, New York: Oxford University Press, 347-59.

Demsetz, Harold, (1967), “Toward a Theory of Property Rights," American Economic Review 57(2): 347-59.

Getches, David H., (1997), Water Law in a Nut Shell, St. Paul, West Publishing Co.

Glennon, Robert Jerome, (2002) Water Follies: Groundwater Pumping and the Fate of America's Fresh Waters, Washington D.C.: Island Press.

Glennon, Robert Jerome, (2009), Unquenchable: America's Water Crisis and What to do about It, Washington D.C.: Island Press. 
Haddad, Brent M. (2000), Rivers of Gold: Designing Markets to Allocate Water in California, Washington D.C.: Island Press.

Hanemann, W.M. (2006),'The Economic Conception of Water," in Peter P. Rogers, M. Ramón Llamas, and Luis Martinez Cortina, eds., Water Crisis: Myth or Reality? Abingdon, Oxford: Taylor and Francis, 61-91.

Hanak, Ellen (2003), Who Should be Allowed to Sell Water in California? Third-Party Issues and the Water Market, San Francisco: Public Policy Institute of California.

Hansen, Zeynep K. and Gary D. Libecap, (2004a), "The Allocation of Property Rights to Land: U.S. Land Policy and Farm Failure in the Northern Great Plains," Explorations in Economic History 41: 103-29.

Hansen, Zeynep K. and Gary D. Libecap, (2004b), "Small Farms, Externalities, and the Dust Bowl of the 1930s," Journal of Political Economy, 112 (3): 665-94.

Howe, Charles W., Dennis R. Schurmeier, and W. Douglas Shaw, Jr., (1986), "Innovative Approaches to Water Allocation: The Potential for Water Markets," Water Resources Research, 22 (4): 439-45.

Howe, Charles W. and Christopher Goemans, (2003), "Water Transfers and their Impacts: Lessons from Three Colorado Water Markets," Journal of the American Water Resources Association, October: 1055-65.

Howitt, Richard and Kristiana Hansen (2005), “The Evolving Western Water Markets,” Choices 20(1): 59-63.

Hutchins, Wells A.,(1929), Mutual Irrigation Companies, Technical Bulletin No. 82, U.S. Department of Agriculture, Washington D.C.: Government Printing Office.

Hutchins, Wells A.,(1930), Commercial Irrigation Companies, Technical Bulletin No. 177, U.S. Department of Agriculture, Washington D.C.: Government Printing Office.

Hutchins, Wells A.,(1931), Irrigation Districts, Their Organization, Operation and Financing, Technical Bulletin No. 254, U.S. Department of Agriculture, Washington D.C.: Government Printing Office.

Johnson, Ronald N., Micha Gisser, and Michael Werner, (1981), "The Definition of a Surface Water Right and Transferability," Journal of Law and Economics 24 (2): 273-88.

Johnson, Ronald N. and Gary D. Libecap, (1982), "Contracting Problems and Regulation: The Case of the Fishery," American Economic Review 72(5): 1005-22. 
Kanazawa, Mark T. (1998), "Efficiency in Western Water Law: The Development of the California Doctrine, 1850-1911," Journal of Legal Studies 27 (1): 159-185.

Kanazawa, Mark T, (2010), "The Extralegal Origins of First Possession: Water Law during the California Gold Rush,” working paper, Department of Economics, Carleton College.

Klein, Benjamin, Robert G. Crawford, and Armen A. Alchian, (1978), "Vertical Integration, Appropriable Rents, and the Competitive Contracting Process," Journal of Law and Economics 21(2): 297-326.

Knight, Oliver, (1956), "Correcting Nature's Error: The Colorado-Big Thompson Project," Agricultural History 30(4): 157-69.

Landry, Clay, (2010), Water Markets Data, WestWater Research, Boise, Idaho.

Leshy, John D. (1982), "Irrigation Districts in a Changing West-An Overview," Arizona State Law Journal: 345-76.

Libecap, Gary D., (2007), "The Assignment of Property Rights on the Western Frontier: Lessons for Contemporary Environmental and Resource Policy," Journal of Economic History 67 (2): $257-91$.

Libecap, Gary D., (2008a), “Chinatown Revisited: Owens Valley and Los Angeles_Bargaining Costs and Fairness Perceptions of the First Major Water Rights Exchange, Journal of Law, Economics and Organization 25 (2): 311-338.

Libecap, Gary D., (2008b), "Open-Access Losses and Delay in the Assignment of Property Rights," Arizona Law Review 50(2): 379-408.

Libecap, Gary D. and James Smith, (1999), "The Self-Enforcing Provisions of Oil and Gas Unit Operating Agreements: Theory and Evidence," Journal of Law, Economics, and Organization 15(2): 526-48.

Libecap Gary D, and Zeynep K. Hansen, (2002), “'Rain Follows the Plow’ and Dryfarming Doctrine: The Climate Information Problem and Homestead Failure in the Upper Great Plains, 1890-1925," Journal of Economic History, 62 (1): 86-120.

Lueck, Dean, (1995), "The Rule of First Possession and the Design of the Law," Journal of Law and Economics 38 (2): 393-436.

MacDonnell, Lawrence J., (1990), The Water Transfer Process as a Management Option for Meeting Changing Water Demands, Vol. I., Washington D.C.: USGS.

Meinig, D.W., (1993). The Shaping of America: A Geographical Perspective on 500 Years of History, Volume 2: Continental America, 1800-1867. New Haven: Yale University Press. 
Nordhaus, William, (2008), A Question of Balance, New Haven: Yale University Press.

North, Douglass C., (1990), Institutions, Institutional Change, and Economic Performance, New York: Cambridge University Press.

Northwest Economic Associates (2004), Third Party Impacts of the Palo Verde Land Management, Crop Rotation and Water Supply Program, Draft Report” March 29, Sacramento.

Ostrom, Elinor, (1990), Governing the Commons: The Evolution of Institutions for Collective Action, New York: Cambridge University Press.

Pindyck, Robert S. (2010), "Modeling the Impact of Warming in Climate Change Economics," in Gary D. Libecap and Richard Steckel, eds., The Economics of Climate Change: Adaptations Past and Present, Chicago: University of Chicago Press and NBER, forthcoming.

Pisani, Donald J., (1984), From the Family Farm to Agribusiness: The Irrigation Crusade in California and the West, 1850-1921 Berkeley: University of California Press.

Pisani, Donald J. (1992), To Reclaim and Divided West: Water, Law, and Public Policy, 18481902, Albuquerque: University of New Mexico Press.

Powell, John Wesley, (1879), Report on the Lands of the Arid Region of the United States,45 Congress, 2nd Session, Executive Document, No. 73. Washington D.C.: Government Printing Office.

Ragab, R. and Christel Prudhomme, (2002), "Climate Change and Water Resources Management in Arid and Semi-arid Regions: Prospective and Challenges for the 21st Century" Biosystems Engineering 81 (1): 3-34.

Richards, Elizabeth Hartwell, (2008), Over-allocation and the Doctrine of Prior Appropriation: Water Rights Settlement Agreements in New Mexico, PhD Dissertation, Stanford University.

Rose, Carol M, (1990), "Energy and Efficiency in the Realignment of Common-Law Water Rights "The Journal of Legal Studies," 19 (2): 261-296

Rosen, Michael D. and Richard J. Sexton, (1993), "Irrigation Districts and Water Markets: An Application of Cooperative Decision-Making Theory," Land Economics, 69(1) 39-53.

Scarborough, Brandon (2010), Environmental Water Markets: Restoring Streams through Trade, PERC, Bozeman, MT.

Smith, Henry E., (2008) "Governing Water: The Semicommons of Fluid Property Rights," Arizona Law Review 50 (2): 445- 78. 
Stewart, I., D.R. Cayan, and M.D. Dettinger, (2005), "Changes toward Earlier Streamflow Timing across Western North America,” Journal of Climate, 18 (April): 1136-55.

Thompson, Barton H., (1993), "Institutional Perspectives on Water Policy and Markets," California Law Review 81: 673-764.

Tyler, Daniel, (1992), The Last Water Hole in the West: The Colorado-Big Thompson Project and the Northern Colorado Conservancy District, Boulder: University of Colorado Press.

U.S. Department of Commerce, (1940), Census of Irrigation-United States Summary, Washington D.C.: Government Printing Office.

Young, Robert A., (1986), "Why are There so Few Transactions Among Water Users?" American Journal of Agricultural Economics, December: 1143-51.

Wahl, Richard W., (1989) Markets for Federal Water: Subsidies, Property Rights, and the Bureau of Reclamation, Washington D.C.: Resources for the Future.

Weitzman, Martin L., (2010), “Additive Damages, Fat-Tailed Climate Dynamics, and Uncertain Discounting, in Gary D. Libecap and Richard Steckel, eds., The Economics of Climate Change: Adaptations Past and Present, Chicago: University of Chicago Press and NBER, forthcoming.

Wiggins, Steven N. and Gary D. Libecap, (1985), “Oil Field Unitization: Contractual Failure in the Presence of Imperfect Information," American Economic Review 75(3): 368-85.

Williamson, Oliver E., (1971), “The Vertical Integration of Production: Market Failure Considerations," American Economic Review 61(2): 112-23.

World Water Assessment Program, (2009). The United Nations World Water Development Report 3: Water in a Changing World. Paris: UNESCO.

Worster, Donald, (2001), A River Running West: the Life of John Wesley Powell, New York: Oxford University Press. 